\title{
Zeolite and Hucalcia as Coating Material for Improving Quality of NPK Fertilizer in Costal Sandy Soil
}

\author{
Sulakhudin, Abdul Syukur and Bambang Hendro Sunarminto \\ Department of Soil Science, Faculty of Agriculture, Gadjah Mada University, Bulaksumur Campuss, Flora \\ Street No 1, Bulaksumur, Yogyakarta 55281 Indonesia, Telephone: +620274548814 \\ email: sulakhudin@gmail.com
}

Received 9 June 2010 / accepted 25 April 2011

\begin{abstract}
The growth and yield of plants are mainly a function of the quantity of fertilizer and water. In coastal sandy soil, nutrient losses and dry soils are seriously problems. The objective of the research was to study effect of zeolite and hucalci concentrations as NPK coating materials on NPK qualities i.e. water adsorption and release of N, P and K. The research used a coastal sandy soil as media. It was conducted in a laboratory of Soil Science Department, Gadjah Mada University from July to August 2009. Experimental design used was a factorial in a completely randomized design. The first factor was hucalci concentration, consisted of $10 \%\left(\mathrm{H}_{1}\right), 20 \%\left(\mathrm{H}_{2}\right)$, and $30 \%\left(\mathrm{H}_{3}\right)$. The second factor was zeolite concentration, consisted of $25 \%\left(\mathrm{Z}_{1}\right), 50 \%\left(\mathrm{Z}_{2}\right), 75 \%\left(\mathrm{Z}_{3}\right)$, and $100 \%\left(\mathrm{Z}_{4}\right)$. NPK fertilizer (without coating) used as a control. The results showed that hucalci and zeolite had a capability to increase water adsorption and to retard the release of N, P, K. The coated NPK with hucalci $30 \%$ and zeolite $100 \%$ had the highest quality in water absorption, water retention and release of nutrients.
\end{abstract}

Keywords: Coastal sandy soil, humic-calcium, NPK fertilizer, zeolite

\section{INTRODUCTION}

The growth of plants and their qualities are mainly a function of the quantities of fertilizer and water (Fageria 2009), especially in arid and semiarid regions (Sharifi et al. 1988). Therefore, it is very important to improve the utilization of water resources and fertilizer nutrients (Wu et al. 2008). However, about $40-70 \%$ of nitrogen, $80-90 \%$ of phosphorus, and $50-70 \%$ of potassium of the applied normal fertilizers is lost to the environment and cannot be absorbed by plants, which causes not only large economic and resource losses but also very serious environmental pollution (Wu and Liu 2008). Recently, the use of slow release fertilizers is a new trend to save fertilizer consumption and to minimize environmental pollution (Jarosiewicz and Tomaszewska 2003).

Slow release fertilizers are made to release their nutrient contents gradually and to coincide with the nutrient requirement of a plant (Tyliszczak et al. 2009). These fertilizers can be physically prepared by coating granules of conventional fertilizers with various materials that reduce their

J Trop Soils, Vol. 16, No. 2, 2011: 99-106

ISSN 0852-257X dissolution rate (Tomaszewska et al. 2002). The release and dissolution rates of water-soluble fertilizers depend on the coating materials. The membrane materials developed can be divided into two main varieties, inorganic mineral and organic polymer (Zou et al. 2009). Humic substances were made for membrane material. They can incorporate nitrogen into their structure either directly through chemical reactions or indirectly through microbial activities and subsequent decomposition of microbial biomass (Essington 2004). In general, negative charge in humic substances is originated from dissociation of ion $\mathrm{H}$ from functional group's especially carboxyl and phenol (Andelkovic et al. 2004). Approximately 85 to $90 \%$ negative charged are derived from those groups (Tan 2003). The carboxyl and phenol from $\mathrm{Hs}$, having similar negative charges, are not able to bond ion nitrate; therefore, they become easier subject to leaching. In order to bond the nitrate from urea with humic substances, the process needs cation, i.e. calcium to bridge functional humic group and ion nitrate (Oviasogie and Okolo 2008). Existence of $\mathrm{Ca}$ in between humic and nitrate will create out sphere complex.

In the last decade, agricultural lands are often lack of water due to a long dry season and erratic 
rainfall. It is necessary to increase the water content in the soil around the plant roots. Superabsorbent polymers can store and release water for plant needs (Mohana and Padmanabha 2001). Zeolites are crystalline alumino silicates of elements of sodium, potassium, magnesium and calcium (Ramesh et al. 2010). Zeolite chemically can be written with the empirical formula: $\mathrm{M}_{2} / \mathrm{nO} \cdot \mathrm{Al}_{2} \mathrm{O}_{3} \cdot \mathrm{ySiO}_{2} \cdot \mathrm{wH}_{2} \mathrm{O}$, where $\mathrm{y}$ is 2 or greater, $\mathrm{n}$ is the cation valence, and $\mathrm{w}$ represents the water contained therein (Elly et al. 2006). Zeolites has high value of cation exchange capacity, containing alkali that is used as an alkali cation exchange. Effective zeolites adsorb cations, nutrients (such as $\mathrm{N}$ ) and water (Elliot and Zhang 2005). Nutrients and water absorbed were able to release when the plants need (Wuryaningsih et al. 1998).

Based on the above descriptions, the double coated NPK fertilizers were used to improve the quality of fertilization. The first layer made of humic-calcium complex (hucalci) was capable of control the release of nutrients. The second layer was zeolite capable to store and provide sufficient water for crop needs and maintain soil moisture. This study aimed to find the best composition of outer coating material (zeolite) which was able to retain the optimum water, to find the coating material (hucalci) NPK fertilizer which was able to slowly release the soil nutrients, and to find coating technique of double-coated NPK fertilizer with zeolite and hucalci that was easily applied as long-lasting fertilizer.

\section{MATERIALS AND METHODS}

\section{Preparation of Hucalci and Zeolite}

Preparation of hucalci. Manure were mashed and filtered with a $5 \mathrm{~mm}$ sieve and air dried. The dry cow manure was added with $20 \mathrm{ml}$ of $\mathrm{KOH} 0.5$ $\mathrm{N}$ (Rocha et al. 1998), then was stirred for 15 minutes, aged for 10 minutes, repeated 3 times, and was left for overnight. Afterwards, using a filter paper, the solution was filtered to obtain blackish brown (humic substances). To the amount of 100 $\mathrm{ml}$ of the liquid was mixed and stirred with $0.5 \mathrm{M}$ $\mathrm{CaCl}_{2}$. The sediment (hucalci) was filtered with a filter paper Whatman 42. Sediment left on the filter paper was oven dried at $50^{\circ} \mathrm{C}$. The dry sediment was grinded and ready to use as fertilizer coating material.

Zeolite preparation procedures. To obtain the Gunung Kidul zeolite dominated by Na cation, heating process was performed. The procedure include (a) to obtain a uniform grain size zeolite, the fragments was sifted by 20-30 mesh siever and weighed as much as $800 \mathrm{~g}$ each, (b) $3 \mathrm{M} \mathrm{NaCl}$ solution $(1,600 \mathrm{ml})$ was prepared in order to have the ratio of solid zeolite and the solution $1: 2(\mathrm{w} /$ v), (c) While stirring well, the material were heated at a constant temperature of $100^{\circ} \mathrm{C}$ for 4 hours, d) The next step was gravimetric sifting process. The sifting process was conducted when the washing water became free from $\mathrm{Cl}^{-}$(indicated by $\mathrm{AgNO}_{3}$ ). The fertilizer coating material of zeolite was ready to use.

\section{Formulating of Double-coated NPK Fertilizer}

NPK Zeo-hucalci fertilizer was made from NPK fertilizer with content N, P, and K, respectively by $15 \%$. NPK fertilizer was used as the core of fertilizer to be covered 2 times using humatcalcium (hucalci) and zeolite. The originating of double-coated NPK fertilizer can be divided into two procedures of coating, including, (1) coating of NPK fertilizer with hucalci, and (2) coating with zeolite. The first coating procedure was that, the hucalci and starch were mixed up evenly with a certain ratio to obtain hucalci concentration of $10 \%, 20 \%$, and $30 \%$. Subsequently, NPK fertilizer was put into mixed hucalci and mingled until the NPK granule fertilizer was coated homogeneously. Afterward, the coated NPK fertilizer was placed in the tubes and was dried with hot air until the mixed hucalci layer glued on the NPK fertilizer firmly. This experiment obtained 3 kinds of coated NPK fertilizer hucalci $10 \%\left(\mathrm{H}_{1}\right), 20 \%\left(\mathrm{H}_{2}\right)$ and $30 \%\left(\mathrm{H}_{3}\right)$.

The second coating of NPK fertilizer with zeolite was that, the hucalci coated NPK fertilizer $10 \%, 20 \%$ and $30 \%$ was placed into the mixture of zeolite and starch concentration arranged as as follows: $25 \%\left(\mathrm{Z}_{1}\right), 50 \%\left(\mathrm{Z}_{2}\right), 75 \%\left(\mathrm{Z}_{3}\right)$ and $100 \%$ $\left(\mathrm{Z}_{4}\right)$. After that, they were mixed up thoroughly, blown with hot air in the dryer until the layer of zeolite glued on NPK fertilizer which has been coated with the mixed hucalci. Hence, it was obtained 12 kinds of Zeo-hucalci double-coated NPK fertilizer, namely: $\mathrm{Z}_{1} \mathrm{H}_{1}, \mathrm{Z}_{2} \mathrm{H}_{1}, \mathrm{Z}_{3} \mathrm{H}_{1}, \mathrm{Z}_{4} \mathrm{H}_{1}$, $\mathrm{Z}_{1} \mathrm{H}_{2}, \mathrm{Z}_{2} \mathrm{H}_{2}, \mathrm{Z}_{3} \mathrm{H}_{2}, \mathrm{Z}_{4} \mathrm{H}_{2}, \mathrm{Z}_{1} \mathrm{H}_{3}, \mathrm{Z}_{2} \mathrm{H}_{1}, \mathrm{Z}_{3} \mathrm{H}_{1}$, and $\mathrm{Z}_{4} \mathrm{H}_{1}$.

The next step was the examination of NPK zeohucalci fertilizer which can be divided into three procedures, including: the investigation of the water absorption capability, the nature of slowly release of nutrient of Zeo-hucalci double coated, and the water retention capacity of NPK fertilizer in the double-layered in sandy soil. 


\section{Investigation of the Water Absorption}

Five gram of NPK Zeo-hucalci fertilizer was submerged under running tap water for 15 minute. The wet NPK Zeo-hucalci fertilizer was filtrated through 80-mesh sieve to remove nonabsorbed water and was weighed. The water absorbency was calculated using the following equation:

$$
\mathrm{WA}=(\mathrm{M}-\mathrm{M} 0) / \mathrm{M} 0
$$

$\mathrm{M}$ and M0 denoted the weight of wet NPK Zeohucalci fertilizer and the weight $(\mathrm{g})$ of the dry NPK Zeo-hucalci fertilizer, respectively, and WA was the water absorbency per gram of NPK Zeo-hucalci fertilizer.

\section{Investigation of Nature of Slow Release NPK Zeo-hucalci Fertilizer in Sandy Soil}

To study the slow-release behavior of NPK Zeo-hucalci fertilizer in sandy soil, the following experiment was carried out, $1 \mathrm{~g}$ of NPK Zeo-hucalci fertilizer was mixed well with $180 \mathrm{~g}$ of dry sandy soil (below $2 \mathrm{~mm}$ in diameter) and kept in a 200 $\mathrm{mL}$ plastic beaker properly covered and incubated for different periods at room temperature. Throughout the experiment, the soil was maintained at $30 \mathrm{wt} \%$ water-holding capacity by weighing and adding distilled water if necessary, periodically. For the control, without fertilizer and NPK fertilizer, (the total contents of $\mathrm{N}, \mathrm{P}$, and $\mathrm{K}$ were the same as that of 1 gram NPK Zeo-hucalci fertilizer), respectively, were also carried out. The remaining NPK compound fertilizer granular and NPK Zeohucalci fertilizer in the beakers were picked out and washed well by distilled water after each incubated period (day 1, 3, 5, 10, 15, 20, 25 and 30), and then dried at $70^{\circ} \mathrm{C}$ to a constant weight to be estimated for the contents of N, P and $\mathrm{K}$. The contents of $\mathrm{N}$ was measured with Kjeldahl distillation method, while $\mathrm{P}$ was determined colorimetrically after treating with ammonium molybdate and stannous chloride at a wavelength of $660 \mathrm{~nm}$. K was estimated by an element analysis instrument and atomic absorption spectrophotometer with double acid method (Tan 1996).

\section{Measurement of the Water-Retention of NPK Zeo-hucalci in Sandy Soil}

A two gram sample of NPK Zeo-hucalci fertilizer was mixed well with $200 \mathrm{~g}$ of dry sandy soil (below $2 \mathrm{~mm}$ in diameter) and kept in a plastic beaker and then $200 \mathrm{~g}$ of tap water was slowly added into the beaker and weighed $\left(\mathrm{W}_{1}\right)$. A controlled experiment, i.e., without NPK Zeo-hucalci fertilizer, was also carried out. The beakers were maintained at room temperature and were weighed every 5 days
$\left(\mathrm{W}_{\mathrm{i}}\right)$ over a period of 30 days. The water evaporation ratio (W\%) of soil was calculated using the following equation:

$$
\mathrm{W} \%=100 \times\left(\mathrm{W}_{1}-\mathrm{W}_{\mathrm{i}}\right) / 200 .
$$

\section{RESULTS AND DISCUSSION}

Soil properties used in the experiment are shown in Table 1. Soil was characterized as having sand texture, and the bulk density $\left(1.99 \mathrm{~g} \mathrm{~cm}^{-1}\right)$ was considered high (Hazelton and Murphy 2007). The soil reaction was considered neutral (soil $\mathrm{pH}$ 7.08) with content of nutrient was very low. The level of cation exchange capacity (CEC) and organic matter were low. Consequently, the coastal sandy soil to held water was low. According Sulakhudin et al. (2010) the percentage of water fills pores was very small $(0.66 \%)$. Therefore, the available water capacity (AWC) was very low $2.10 \%$.

The high sand particles, porosity, and permeability with the low CEC of this coastal sandy soil could support nutrients losses. An average annual leaching rate of $63 \mathrm{~kg} \mathrm{NO}_{3}^{-}-\mathrm{N} \mathrm{ha}^{-1}$ was

Table 1. Selected physic-chemical properties of

\begin{tabular}{|c|c|c|}
\hline Soil properties & Value & Level \\
\hline \multicolumn{3}{|l|}{ Soil fractions (\%) } \\
\hline clay & 3.00 & - \\
\hline silt & 7.00 & - \\
\hline sand & & - \\
\hline Texture class & sand & \\
\hline $\mathrm{pH} \mathrm{H} \mathrm{H}_{2} \mathrm{O}$ & 7.08 & Neutral* \\
\hline $\mathrm{pH} \mathrm{KCl}$ & 5.27 & Medium \\
\hline $\mathrm{EC}(\mathrm{mS})$ & 0.20 & \\
\hline Total organic $\mathrm{C}(\%)$ & 0.07 & Very low* \\
\hline Organic matter $(\%)$ & 0.11 & Very low* \\
\hline Total N (\%) & 0.01 & Very low* \\
\hline $\mathrm{N}-\mathrm{NO}_{3}^{-}(\mathrm{ppm})$ & 4.23 & Very low* \\
\hline $\mathrm{N}-\mathrm{NH}_{4}{ }^{+}(\mathrm{ppm})$ & 0.72 & Very low* \\
\hline $\mathrm{C} / \mathrm{Nratio}$ & 7.00 & low* \\
\hline A vailable $\mathrm{P}$ (ppm) & 6.66 & Very low* \\
\hline Exchange able $\mathrm{K}\left(\mathrm{cmol}(+) \mathrm{kg}^{-1}\right)$ & 0.18 & low* \\
\hline Exchange able $\mathrm{Ca}\left(\mathrm{cmol}(+) \mathrm{kg}^{-1}\right)$ & 0.24 & Very low* \\
\hline $\operatorname{CEC}\left(\mathrm{cmol}(+) \mathrm{kg}^{-1}\right)$ & 3.67 & Very low* \\
\hline Bulk density $\left(\mathrm{g} \mathrm{cm}^{-3}\right)$ & 1.99 & - \\
\hline Particle density $\left(\mathrm{g} \mathrm{cm}^{-3}\right)$ & 3.57 & - \\
\hline Porosity (\%) & & Very high* \\
\hline
\end{tabular}
the experimental soil.

Source *: Hazelton and Murphy (2007). 
examined for sandy soils as compared to $16 \mathrm{~kg} \mathrm{NO}_{3}$ $-\mathrm{N}$ ha $^{-1}$ for heavier arable soils (Neinder and Benbi 2008).

\section{Formulation of double-coated NPK fertilizer}

The third kind NPK fertilizer was coated by hucalci at concentrations of 10,20 and $30 \%$. Hucalci coating NPK fertilizer indicated the brighter colors than NPK fertilizer. But the color between the concentratin of 10,20 and $30 \%$ was almost the same. Third NPK fertilizer hucalci then coated with a zeolite which had been activated by 4 levels concentration of a $25,50,75$ and $100 \%$, thus obtained 12 kinds of fertilizer Zeo-hucalci. This second coating caused changes in the original color NPK fertilizer. The color of fertilizer was brick red to gray (Figure 1).

\section{Testing the Water Absorption}

Test results of water absorption of the NPK Zeo-hucalci fertilizers can be seen in Table 2. The zeolite concentration of $100 \%$ has the highest ability to absorb water $44.77 \%$, while hucalci concentration of $30 \%$ was $40.09 \%$. The ability of water zeolite concentration to absorb water was significantly different with $75 \%, 50 \%, 25 \%$ and controls (Table 2). The high ability to absorb water was caused by the amount of water adsorbed by zeolite, in which the thicker the zeolite coating, the greater the ability to absorb water. According to Elly et al. (2006) zeolite is a complex structure which is crystalline inorganic polymers based on an expanded tetrahedral framework infinite from $\mathrm{AlO}_{4}$ and $\mathrm{SiO}_{4}$ and connected to each other through joint distribution of oxygen ions. This framework structure contains channels filled by cations and water molecules.

The ability of humic substances to absorb water because of humic substances contain many carboxylic functional group (-COOH). According to Tan (1998) carboxylic have strong attraction to water molecules and water can be bound through a single bond or hydrogen multi bonds. Dissociation of carboxylic groups that can generate a negative charge electrostatically attracts water molecules through the positive pole of water molecules. Colloidal nature of humic substances that have a specific surface area is very large so that the water binding capacity is also very large. Table 2 also showed that the concentration of zeolite and hucalci did not have interaction because mechanism zeolite to absorb water differed with hucalci. The zeolite absorb water with the framework structure that can be filled by water, while hucalci through attraction to water molecules.

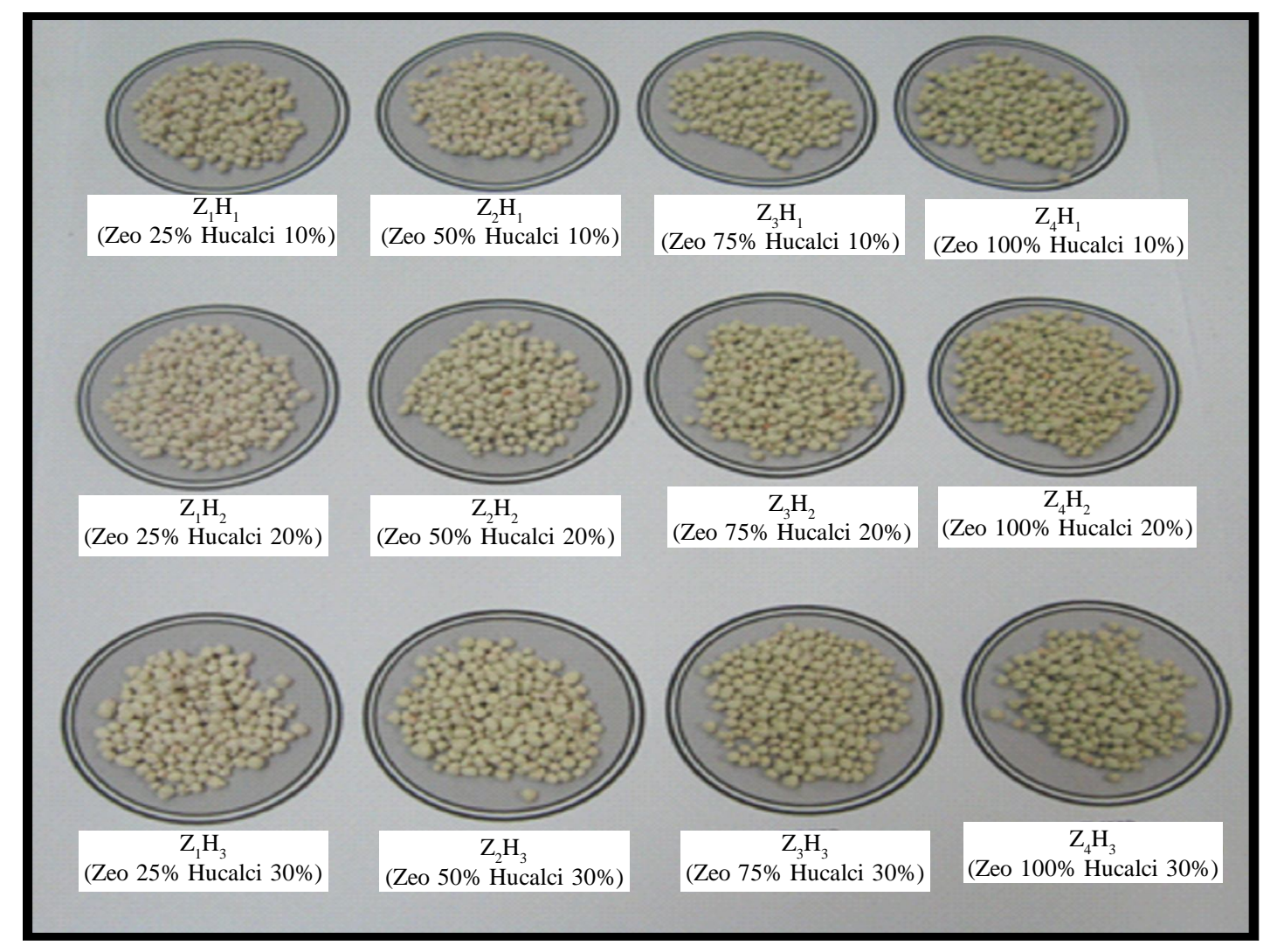

Figure 1. Several types of NPK Zeo-hucalci fertilizers. 
Table 2. The absorption of water, nutrient release and water evaporation ratio in 30 days of several kinds of zeo-hucalci fertilizers.

\begin{tabular}{|c|c|c|c|c|c|}
\hline \multirow{2}{*}{ Treatments } & \multirow{2}{*}{$\begin{array}{l}\text { Water absorption } \\
\qquad\left(\mathrm{g} \mathrm{g}^{-1}\right)\end{array}$} & \multicolumn{3}{|c|}{ Release of nutrients (\%) in 30 days } & \multirow{2}{*}{$\begin{array}{l}\text { Water evaporation } \\
\text { ratio }(\%) \text { in } 30 \text { days }\end{array}$} \\
\hline & & $\mathrm{N}$ & $\mathrm{P}$ & $\mathrm{K}$ & \\
\hline \multicolumn{6}{|c|}{ Concentration of zeolite } \\
\hline $0 \%$ & $14.79 \mathrm{e}$ & $87.74 \mathrm{a}$ & $95.13 \mathrm{a}$ & $55.69 \mathrm{~b}$ & $3.63 \mathrm{a}$ \\
\hline $25 \%$ & $34.74 \mathrm{~d}$ & $83.50 \mathrm{a}$ & $94.28 \mathrm{a}$ & $69.47 \mathrm{a}$ & $3.04 \mathrm{ab}$ \\
\hline $50 \%$ & $37.99 \mathrm{c}$ & $79.93 \mathrm{a}$ & $93.48 \mathrm{a}$ & $63.13 \mathrm{a}$ & $2.17 \mathrm{bc}$ \\
\hline $75 \%$ & $39.56 \mathrm{~b}$ & $68.30 \mathrm{~b}$ & $90.68 \mathrm{~b}$ & $52.33 \mathrm{~b}$ & $1.96 \mathrm{bc}$ \\
\hline $100 \%$ & $44.77 \mathrm{a}$ & $61.34 \mathrm{~b}$ & $87.24 \mathrm{c}$ & $51.62 \mathrm{~b}$ & $1.64 \mathrm{c}$ \\
\hline \multicolumn{6}{|c|}{ Concentration of hucalci } \\
\hline $0 \%$ & $14.79 \mathrm{c}$ & 87.74 a & $95.13 \mathrm{a}$ & $55.69 \mathrm{a}$ & $3.36 \mathrm{a}$ \\
\hline $10 \%$ & $38.16 \mathrm{~b}$ & $75.06 \mathrm{~b}$ & $93.04 \mathrm{ab}$ & $58.72 \mathrm{a}$ & $2.27 \mathrm{~b}$ \\
\hline $20 \%$ & $39.56 \mathrm{a}$ & $73.46 \mathrm{~b}$ & $92.02 \mathrm{~b}$ & 60.18 a & $2.23 \mathrm{~b}$ \\
\hline $30 \%$ & $40.09 \mathrm{a}$ & $71.30 \mathrm{~b}$ & $89.20 \mathrm{c}$ & $58.50 \mathrm{a}$ & $2.12 \mathrm{~b}$ \\
\hline Interaction & $(-)$ & $(-)$ & $(+)$ & $(+)$ & $(-)$ \\
\hline
\end{tabular}

Note: In one column and the kind of treatment, numbers followed by same letters in one column were not difference based on a $5 \%$ DMRT test.

Table 2 also shows the higher the concentration the greater the ability of zeolite adsorbed water. Compared to the control (without coating of NPK fertilizer) the weight of water absorbed was nearly two times the weight of NPK fertilizer.

\section{Slow Release Behavior of NPK Zeo-hucalci in Sandy Soil}

One of the most important characteristic of the NPK Zeo-hucalci fertilizer prepared was its slowrelease property. Figures 2-4 show the slow release

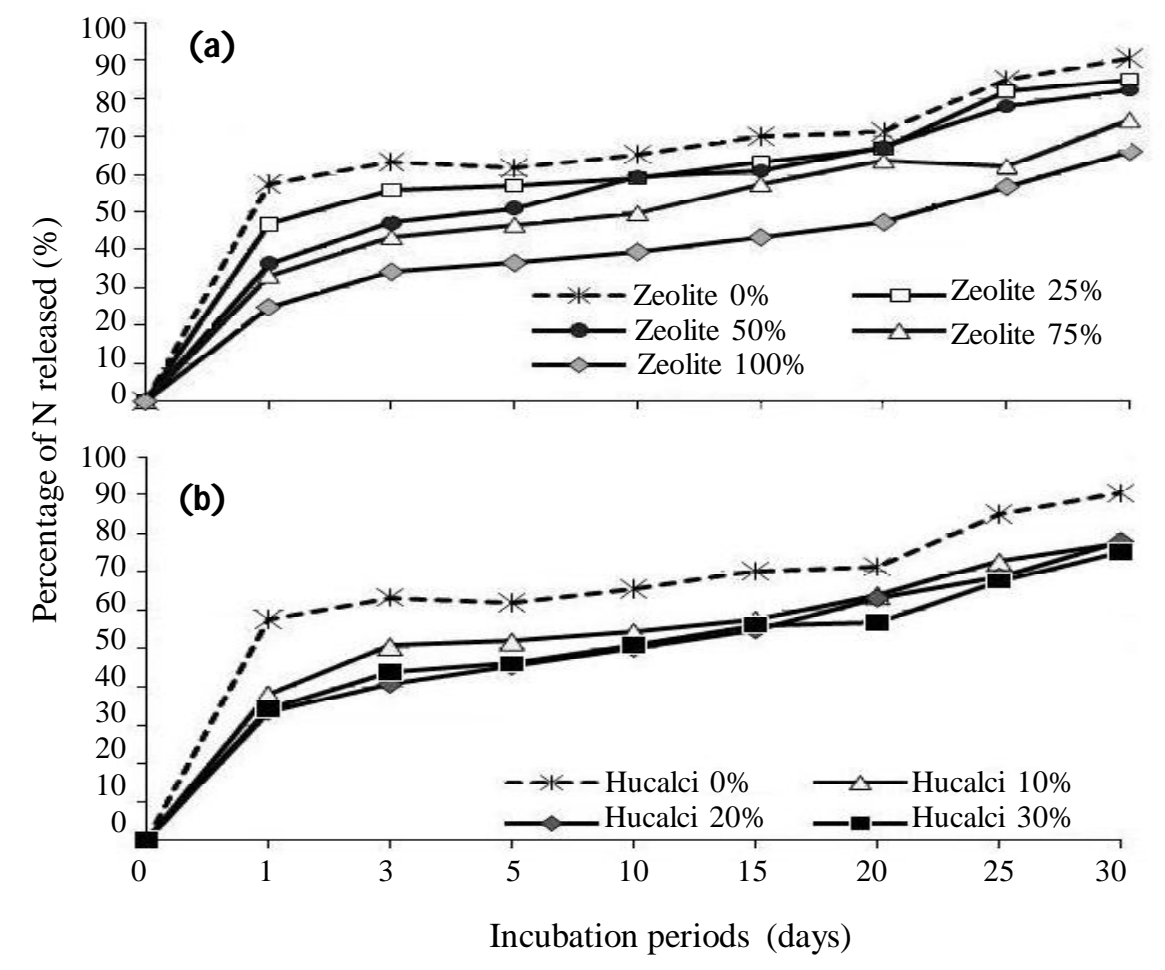

Figure 2. The effect of zeolite (a) and hucalci (b) as coating material of NPK fertilizer on total $\mathrm{N}(\%)$ during incubation periods. 
behaviors of N, P, and $\mathrm{K}$ in uncoated NPK fertilizer and NPK Zeo-hucalci fertilizer in sandy soil, respectively.

The $\mathrm{N}$ nutrient release can be seen from the first day. It was most likely because of $\mathrm{N}$ elements is mobile, especially in the form of volatile gases, either as ammonia or nitrogen oxides (Rosliza et al. 2009). $\mathrm{N}$ was rapidly released until the end of the time (30 days). Figure 2a shows that the release of N from coated NPK with concentration $100 \%$ of zeolite shows a relatively more restrained than the other concentration. Until 30 days, coated NPK with $100 \%$ zeolite concentration released $\mathrm{N}$ as much as $61.34 \%$ which were significantly lower than NPK fertilizer as control (> 80\%). Similarly, coated NPK with $30 \%$ hucalci was lower than other concentration. The total release was $\mathrm{N}$ and $\mathrm{K}$ in NPK Zeo-hucalci fertilizer was less ( $80 \mathrm{wt} \%$ ) by 30 days (Table 2). These results showed that the slow-release properties of NPK Zeo-hucalci fertilizer matched up to the standard of slow-release fertilizers of the Committee of European Normalization (Trenkel 2010). According Elliot and Zhang (2005) the slow release of $\mathrm{N}$ nutrient is controlled by two mechanisms (i) physical encapsulation and (ii) ion exchange of $\mathrm{NH}_{4}^{+}$into zeolite.

The pattern of $\mathrm{P}$ nutrient release differed from the pattern of $\mathrm{N}$ and $\mathrm{K}$ nutrient release. Figure $3 \mathrm{a}$ and $3 \mathrm{~b}$ show that the high release of $\mathrm{P}$ from several kinds of zeolite and hucalci concentration were on 10 day and then increased until 30 day. Comparing to the other concentrations, the concentrations of $100 \%$ zeolite (Figure 3a) and 30\% hucalci released the smallest amount of P. The coated NPK with $100 \%$ zeolite concentration release $87.24 \% \mathrm{P}$ in 30 days, while the control (NPK fertilizer) released as much as $95.13 \%$. So that, coated NPK with $100 \%$ zeolite concentration retaind $\mathrm{P}$ about $8 \%$ more than NPK fertilizer. The release of P from zeohucalci fertilizer was greater than the release of $\mathrm{N}$ and $\mathrm{K}$ which caused by $\mathrm{P}$ was released in the form of $\mathrm{H}_{2} \mathrm{PO}_{4}$ and $\mathrm{HPO}_{4}=$ and it had a negative charge that could not be bound by the negatively charged of zeolite site as much as P material fertilizer.

Figure $4 \mathrm{a}$ and $4 \mathrm{~b}$ shows that the pattern of released $\mathrm{K}$ was relatively stable, which was began in the first day, then increased over the observation period and reached its peak at the end of the observation period (30 days). Those was expected because $\mathrm{K}$ from fertilizer was bound for the time being by sites absorption of zeolite (Elliot and Zhang 2005), and then released slowly over the observation period.

Zeo-hucalci fertilizers of $\mathrm{Z}_{4} \mathrm{H}_{3}$ type released $\mathrm{K}$ more restrained than the other types of Zeohucalci fertilizer. At the end of the observation period, it showed that Zeo-hucalci fertilizer of $\mathrm{Z}_{4} \mathrm{H}_{3}$ type relatively released lower $\mathrm{K}$ nutrient, i.e. approximately $51.58 \%$. This result was lower than Wu et al. (2008) that K released from NPK fertilizer

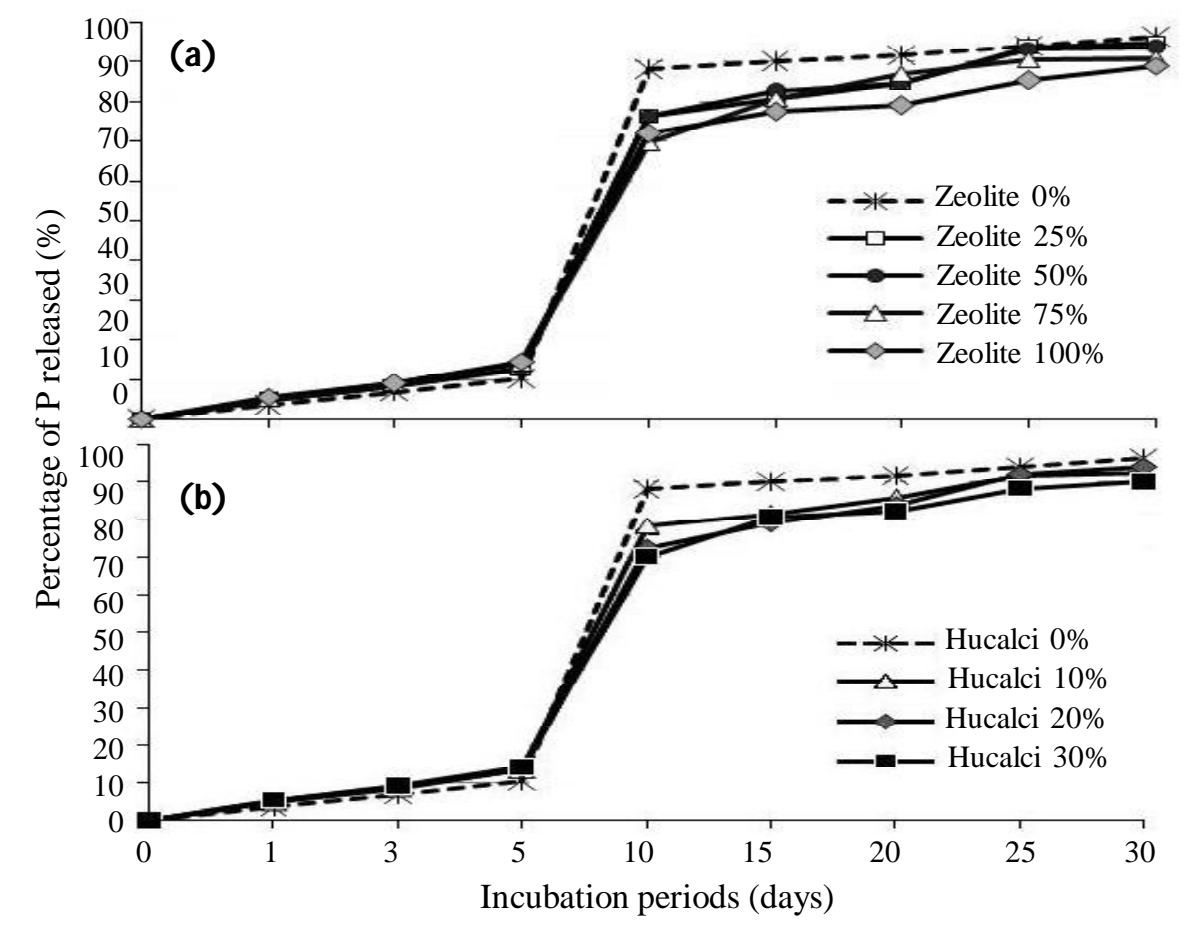

Figure 3. Effect of zeolite (a) and hucalci (b) as coating material of NPK fertilizer on total $\mathrm{P}(\%)$ during incubation periods. 


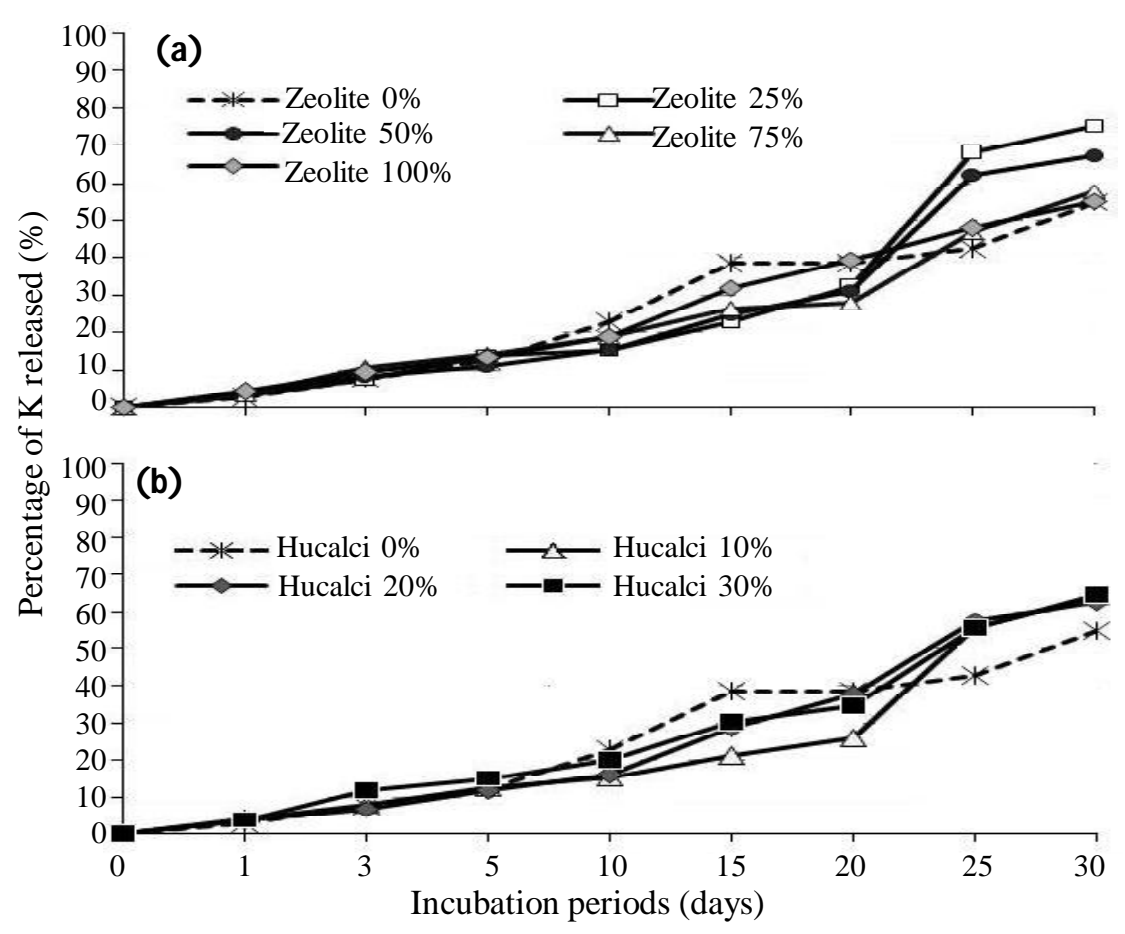

Figure 4. Effect of zeolite (a) and hucalci (b) as coating material of NPK fertilizer on total $\mathrm{K}(\%)$ during incubation periods.

which was coated with citosan and poly (acylic) acid/diatomite containing $68 \%$ urea was at 30 days.

\section{Water-retention Behavior of NPK Zeo-hucalci Fertilizer in Sandy Soil}

Beside its slow-release property, one of the most important characters of NPK Zeo-hucalci fertilizer was its water-retention capacity or, in other words, its effective utilization of water in arid and desert regions. Figure 5 shows that evaporation rate of soil with NPK Zeo-hucalci fertilizer was obviously smaller than the sandy soil without fertilizer. According to Bernardie et al. (2010) concentrated zeolite increased water retention and the available water capacity of a sandy soil when it was used as a soil conditioner.

All types of zeo-hucalci fertilizer could store more water than the control (NPK fertilizer). This could be ascertained from the amount of water that evaporated which was smaller than NPK fertilizer. Figure 5 also shows the relationship between the concentrations of zeolite with the ability to reduce water loss due to evaporation. The lower the concentration of zeolite the more water evaporates. Zeo-hucalci fertilizer of $\mathrm{Z}_{4} \mathrm{H}_{3}$ type which containing the highest concentrations of zeolite and hucalci showed the least water loss. This means that more water could be stored in the Zeohucalci fertilizer of $\mathrm{Z}_{4} \mathrm{H}_{3}$ type.
Based on laboratory water absorption test, the best formula of releasing nutrients and water retention of the Zeo-hucalci fertilizer was $\mathrm{Z}_{4} \mathrm{H}_{3}$.

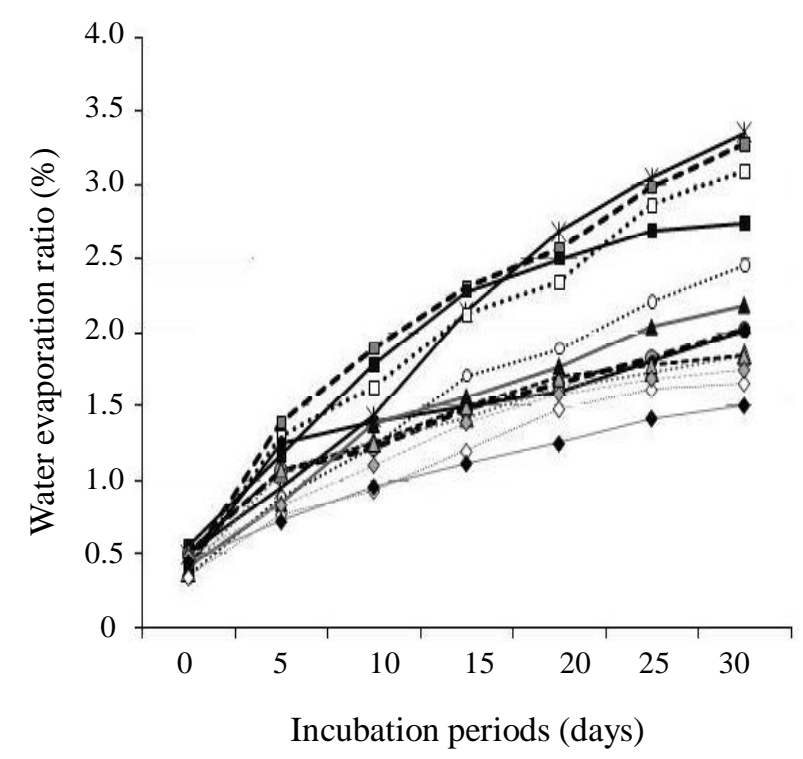

Figure 5. Evaporation of water by several kinds of zeo-hucalci fertilizers. $*=$ NPK, $\cdots \cdot \square \cdot \cdots=\mathrm{Z}_{1} \mathrm{H}_{1}, \cdots-\cdot-\cdot=\mathrm{Z}_{1} \mathrm{H}_{2}, \rightarrow-=\mathrm{Z}_{1} \mathrm{H}_{3}$, $\cdots \cdot \cdots \cdot \cdots=Z_{2} \mathrm{H}_{1},--\circ \cdots=\mathrm{Z}_{2} \mathrm{H}_{2}, \rightarrow=\mathrm{Z}_{2} \mathrm{H}_{3}$, $\cdots \cdot \overrightarrow{* \cdots}=\mathrm{Z}_{3} \mathrm{H}_{1}, \cdots \nleftarrow \cdot \cdot=\mathrm{Z}_{3} \mathrm{H}_{2}, \longrightarrow=$ $\mathrm{Z}_{3} \mathrm{H}_{3}, \diamond=\mathrm{Z}_{4} \mathrm{H}_{1},=\diamond=\mathrm{Z}_{4} \mathrm{H}_{2}$, and $\longrightarrow=\mathrm{Z}_{4} \mathrm{H}_{3}$. 


\section{CONCLUSIONS}

Hucalci and zeolite as coating material were potential to increase water absorption and water retention of NPK fertilizer and to retard N, P, and $\mathrm{K}$ released from the fertilizer. Increasing concentration of hucalci and zeolite resulted in increasing water absorption and water retention, as well as decreased $\mathrm{N}, \mathrm{P}$, and $\mathrm{K}$ release. The coated NPK with $30 \%$ hucalci and $100 \%$ zeolite had the highest quality in water absorption, water retention and release of nutrients.

\section{ACKNOWLEDGEMENT}

This work was supported by Multiyears Program Funds from the Ministry of Education of Indonesia.

\section{REFERENCES}

Andelkovic T, J Perovic, M Purenovic and D Andelkovic. 2004. Destabilization and aggregation of aqueous humic acids solution by metal ions. Phys Chem Tech 3 (I) : 79-85.

Bernardi ACC, PPA Oliviera, MBM Monte, JC Polidoro and FS Barros. 2010. Brazilian sedimentary zeolite use in agriculture. World Congress of Soil Science, Soil Solutions for a Changing World 1 - 6 August 2010, Brisbane, Australia. Published on DVD.

Elliot AD and D Zhang. 2005. Controlled Release Zeolite Fertilizers: A Value Added Product Produced from Fly Ash. World of Coal Ash (WOCA), April 11-15, 2006, Lexington, Kentucky, USA. p. 32.

Elly MU, FA Yasnur and Istadi. 2006. Optimasi pembuatan katalis zeolit $\mathrm{X}$ dari tawas, $\mathrm{NaOH}$ dan water glass dengan response surface methodology. Bull Chem Reac Engine Catal 1 (3): 26-32.

Essington ME. 2004. Soil and Water Chemistry: An integrative approach. CRC Press. Florida, p. 534.

Fageria NK. 2009. The use of nutrients in crop plants. Taylor \& Francis Group, LLC CRC Press. Boca Raton, $430 \mathrm{p}$.

Hazelton PA and B Murphy. 2007. Interpreting soil test results: what do all the numbers mean? [2nd ed.]. CSIRO Publishing. Collingwood VIC 3066 Australia.

Jarosiewicz A and M Tomaszewska. 2003. Controlledrelease NPK fertilizer encapsulated by polymeric membranes. J Agric Food Chem 51: 413-417.

Mohana RK and RM Padmanabha. 2001. Synthesis of novel superabsorbing copolymers for agricultural and horticultural applications. Polym Int 50: 946.

Neinder R and DK Benbi. 2008. Carbon and nitrogen in the terrestrial environment. Springer Science. Germany, 430 p.
Oviasogie PO and PO Okolo. 2008. Effect of pH and concentration on the complexation of calcium ions with humic acid extracted from composted oil palm bunches. Inter J Phys Sci 3 (2): 56-58.

Ramesh, K. A. K. Biswas, J. Somasundaram and A. S. Rao. 2010.Nanoporous zeolites in farming: current status and issues ahead. Review Article. Curr Sci 99 (6): 260-264.

Rocha JC, AH Rosa and M Furlan. 1998. An alternative metodology for the extraction of humic substances from Organic Soils. J Braz Chem Soc 9 (1): 52-56.

Rosliza S, OH Ahmed and NMA Majid. 2009. Controlling Ammonia Volatilization by Mixing Urea with Humic Acid, Fulvic Acid, Triple Superphosphate and Muriate of Potash. Am J Environ Sci 5 (5): 605-609.

Sharifi MR, FC Meinzer, ET Nilsen, PW Rundel, RA Virginia, WM Jarrell, DJ Herman, and PC Clark. 1988. Effect of manipulation of water and nitrogen supplies on the quantitative phenology of Larrea tridentate (Creosote bush) in the Sonoran desert of California. Am J Bot 75: 1163-1174.

Sulakhudin, A Syukur, D Shiddieq and T Yuwono. 2010. Effect of coated urea with humic-calcium on transformation of nitrogen in coastal sandy soil: a soil column method. J Trop Soils 15 (1): 11-18.

Tan KH. 1996. Soil Sampling, Preparation and Analysis. Marcel Dekker, Inc. New York, 408 p.

Tan KH. 2003. Humic Matter in Soil and Environment, Principles and Controversies. Marcel Dekker, Inc., Madison, New York. 386 p.

Tomaszewska M, J Anna and K Krzysztof. 2002. Physical and chemical characteristics of polymer coatings in CRF formulation. Desalination 146 (3): 19-323.

Trenkel ME. 2010. Slow- and Controlled-Release and Stabilized Fertilizers: An Option for Enhancing Nutrient Efficiency in Agriculture. Second edition, IFA, Paris, France, 163 p.

Tyliszczak B, J Polaczek, J Pielichowski and K Pielichowski. 2009. Preparation and properties of biodegradable slow-release PAA superabsorbent matrixes for phosphorus fertilizers. Macromolecular Symposia 279 (1): 236-242.

Wu L and M Liu. 2008. Preparation and properties of chitosan-coated NPK compound fertilizer with controlled-release and water-retention. Carbohydrate Polymers 72: 240-247.

Wu L, M Liu and R Liang. 2008. Preparation and properties of a double-coated slow-release NPK compound fertilizer with superabsorbent and waterretention. Bioresource Tech 99: 547-554.

Wuryaningsih S, S Andyantoro and R Tejasarwana. 1998. Kombinasi limbah hasil tanaman dan zeolit untuk media tanam melati pot. Monograf. Risalah seminar nasional tanaman hias, Jakarta, 16-17 Maret 1998, pp. 52-61 (in Indonesian).

Zou HT, YS Wang, HW Song, YY Han, Y Na, YLZhang, XL Dang, Y Huang and YL Zhang. 2009. The Production of organic-inorganic compound filmcoated urea and the characteristics of its nutrient Release. Agric Sci in China 8 (6): 703-708. 